Supporting information for the manuscript

\title{
Role of Protein Dynamics in Reaction Rate Enhancement by Enzymes
}

Pratul K. Agarwal

\section{Complete Reference}

(48) Case, D. A.; Pearlman, D. A.; Caldwell, J. W.; Cheatham III, T. E.; Wang, J.; Ross, W.

S.; Simmerling, C. L.; Darden, T. A.; Merz, K. M.; Stanton, R. V.; Cheng, A. L.; Vincent, J. J.;

Crowley, M.; Tsui, V.; Gohlke, H.; Radmer, R. J.; Duan, Y.; Pitera, J.; Massova, I.; Seibel, G.

L.; Single, U. C.; Weiner, P. K.; Kollman, P. "AMBER 7," University of California, San

Francisco, 2002. 